Bangladesh J. Plant Taxon. 28(2): 459-463, 2021 (December) (C) 2021 Bangladesh Association of Plant Taxonomists

\title{
FIRST RECORD OF SCYTINOPOGON ANGULISPORUS (PAT.) CORNER FROM BANGLADESH
}

\author{
Fakhruddin Ali Ahmed ${ }^{1}$ and Gazi Mosharof Hossain \\ Department of Botany, Jahangirnagar University, Savar, Dhaka 1342, Bangladesh
}

Keywords: Scytinopogon angulisporus; Clavariaceae; Tengragiri reserve forest; Bangladesh.

The hot humid climatic conditions of Bangladesh are highly congenial for fungi and as such, a rich fungal biodiversity is evident in the country but the fungal flora have not been fully recorded as yet (Shamsi, 2019). To record the fungal flora of mangrove ecosystems in Bangladesh, the authors conducted several extensive field surveys in different mangrove ecosystems, viz. Sundarbans, Haringhata (Pathorghata, Borguan), Sonbunia (Babuganj, Borguna), Tengragiri (Taltoli, Borguna), and Gangamoti (Kuakata) during 2015-2019. To achieve the objective, an exploration made to the Tengragiri mangrove reserve forest in Borguna district of Bangladesh during August 2017 under a research project funded by Bangladesh Ministry of Science and Technology (MOST). During this exploration, a different looking fungus was collected and after a detailed taxonomic investigation on its macro and microscopic features, the specimens finally identified as Scytinopogon angulisporus (Pat.) Corner that belongs to the family Clavariaceae. The species and the genus do not match with any species previously published in relevant literature covering the fungal flora of Bangladesh (Alam and Amin, 2007; Alam et al., 2008; Rumainul and Aminuzzaman, 2016; Hosen and Li, 2017; Tanjim et al., 2019; Hosen and Ge, 2020; Tanni et al., 2020). Therefore the genus Scytinopogon and the species Scytinopogon angulisporus are reported here as the new records for Bangladesh. Detailed taxonomic description with notes on ecology, distribution, representative specimen examined and photographs including photomicrographs and drawing are provided.

Fresh fruiting bodies of $S$. angulisporus were collected, properly processed following the standard procedure described by Prance and Fechner (2017) and deposited at the Department of Botany, Jahangirnagar University with accession number for voucher specimens. Morphological features including shape, size, color etc. were recorded in the field. Microscopic studies were carried out in the laboratory on preserved dry and wet samples. Dry samples mounted in 5\% KOH and Lactophenol-cotton blue. Length and width of basidium, basidiospore and hymenium were measured using ocular micrometer. Photomicrographs were taken under 40X and 100X magnification with Leica DM500 Binocular Microscope. For spore measurement, 25 spores from mature collections were studied. The specimen was identified according to Corner (1950) and Dutta et al. (2012). The taxonomic descriptions along with photographs have been prepared based on both fresh and preserved specimens.

Scytinopogon angulisporus (Pat.) Corner, Ann. Bot. Mem. 1: 648 (1950)

(Fig. 1)

Syn.: Clavaria angulispora Pat., in Patouillard \& Gaillard, Bull. Soc. mycol. Fr. 4(1): 41 (1888); Scytinopogon angulisporus var. curtus Corner, Ann. Bot., Lond., n.s. 16: 701 (1950); S. angulisporus var. gracilis Corner, Monograph of Clavaria and allied Genera, (Annals of Botany

\footnotetext{
${ }^{1}$ Corresponding author. Email: faahmed_ju@yahoo.com
} 
Memoirs No. 1): 701 (1950); S. angulisporus var. parvus Corner, Monograph of Clavaria and allied Genera, (Annals of Botany Memoirs No. 1): 701 (1950); S. parvus (Corner) Douanla-Meli, Biblthca Mycol. 202: 119 (2007).

Systematic position: Fungi, Basidiomycota, Agaricomycotina, Agaricomycetes, Agaricomycetidae, Agaricales, Clavariaceae, Scytinopogon, Scytinopogon angulisporus.

Basidiomes 3.5-9.5 cm high, solitary, form mats or growing in dense tufts, chalk-white, becoming pale yellow with maturity, develop uniform color after drying, palmately branched from a compressed stipe, branching in one plane but twisted, slightly rugulose; branches flattened and narrowly, spathulate, the upper sides of the branches minutely subtomentose, $0.3-0.5 \mathrm{~cm}$ wide in the lower branches, tapering towards the apex, polychotomous below, becoming dichotomous, internodes longer gradually, tips acute to blunt, subulate or subterete, narrowly ligulate; stipe 1.65$4.49 \mathrm{~cm}$ long, $0.22-0.41 \mathrm{~cm}$ in diam., sometimes branched from the base, dilated and flattened below the points of branching; basidiospores (3.6-) 4.2-4.8 (5.1) $\times$ 5.8-7.2 (-7.6) $\mu \mathrm{m}(\mathrm{Q}=1.4-1.5)$, hyaline, ovoid to broadly ellipsoid, often but not always appearing angular in outline, with numerous minute, echinulate outgrowths, hilar appendage up to $1.0 \mu \mathrm{m}$ long, inamyloid; basidia 24.5-25.2 $\times$ 6.1-6.9 $\mu \mathrm{m}$, clavate, hyaline, bi- and/ tetra-sterigmatic; cystidia absent; hymenium covered the whole basidiome except the sterile stipe, thickened upwardly, 53.1-120.2 $\mu \mathrm{m}$; subhymenium well developed, coralloid, composed of narrow hyphae, $4.1 \mu \mathrm{m}$ wide, closely interwoven; trama subparallel, smooth, with thin-walled hyphae, 11.9-16.2 $\mu \mathrm{m}$ wide, clamped; sterile stipe to $2.2-4.3 \mu \mathrm{m}$ wide, smooth, thin-walled, clamped, base of sterile stipe covered by loosely interwoven hyphae.

Ecology: Grown on decaying substances in the forest ground.

Distribution: Commonly distributed in tropical and subtropical regions (Corner, 1970). In Bangladesh, this species found to be grown only in one patch of around $100 \mathrm{~m}^{2}$ area of coastal plantation forest near Tengragiri reserve forest in Borguna district of Bangladesh.

Representative specimen examined: Barguna: Taltoli, Tangragiri, 14.08.2017, Fakhruddin 2044, Fakhruddin 2045, Gazi 20406 and Gazi 20407 (JU).

Scytinopogon is a genus of several species of clavarioid (coral-like) fungi in the family of Clavariaceae with a fundamentally tropical distribution (Desjardin and Perry, 2015). The etymology of the name Scytinopogon refers to its macromorphological resemblance to leather barbs (Donk 1954). The principal characteristic of the genus is spore form and ornamentation, but the exceptionally small size of the spores and very fine ornamentation has limited their use in conventional light microscopy as a specific character.

S. angulisporus is a common taxon in tropical and subtropical regions (Corner, 1970). It has been reported to grow on the forest ground of Africa, Borneo, Brazil, Burma, Cameroons, Congo, Cuba, India, Japan, Java, Madagascar, Malaysia, Mauritius, Nigeria, Panama, Philippines, Solomon Islands, Sumatra, Uganda, USA (Banerjee, 1947; Corner, 1950, 1953, 1966, 1970; Meijer, 2006; Dutta et al., 2012).

The genus Scytinopogon morphologically appears to be similar with the genera Pterula Fr. which is distinguished from the later by the consistency of its basidiomata and the color of its spores (García-Sandoval et al., 2004). S. dealbatus (Rick) Corner, S. robustus (Rick) Corner and S. chartaceum (Pat.) R.H. Petersen are looks alike to newly recorded $S$. angulisporus due to their morphometric features. The robust form appears in S. angulisporus and S. dealbatus could be easily confused for their distinction but the presence of flattened branches with hymenium on one side and angular-nodulose basidiospores and lack of agglutination in hyphae of trama clearly separate $S$. angulisporus from $S$. dealbatus which corroborated with the findings of Corner (1950). Furthermore, the robust form and similar basidiome occurs in S. robustus and S. angulisporus but 
these two species can easily be diagnosed by using both macro and microscopic characters. $S$. angulisporus differs from $S$. robustus by the spore size, presence of crystals and the uninflated hyphae (Corner, 1950 and 1970; García-Sandoval et al., 2004).
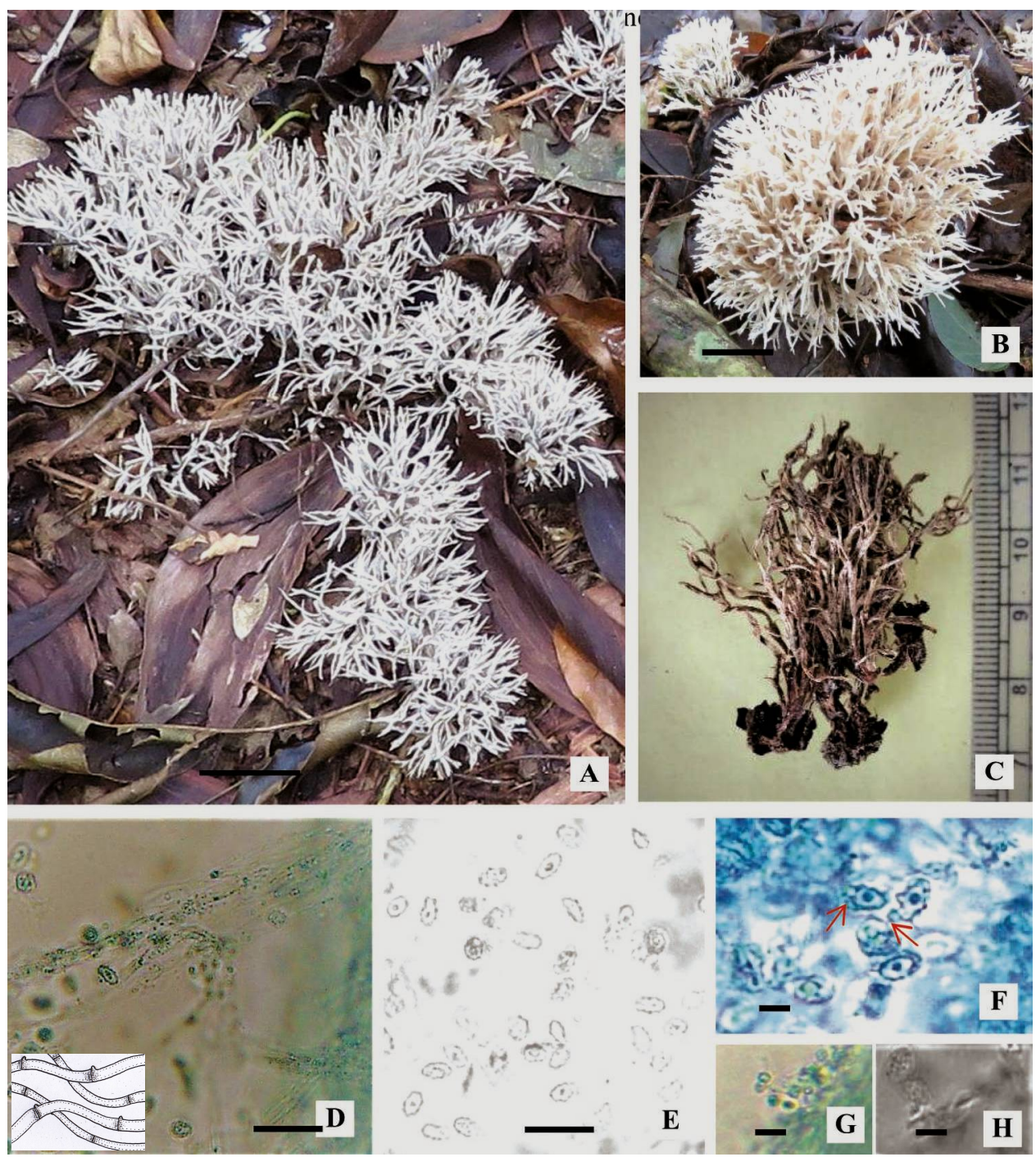

Fig. 1. Scytinopogon angulisporus. $\mathrm{A}=$ Natural habitat $(\mathrm{bar}=15 \mathrm{~cm}) ; \mathrm{B}=$ Fresh basidiomata $(\mathrm{bar}=1.5 \mathrm{~cm}) ; \mathrm{C}$ $=$ Dried fruit body; $\mathrm{D}=$ Monomitic hyphae of hymenium $(40 \mathrm{X}$, bar $=20 \mu \mathrm{m})$, drawing (inset); $\mathrm{E}=$ Echinulate basidiospores $(40 \mathrm{X}, \mathrm{bar}=20) ; \mathrm{F}=$ Basidiospores with hilar appendage (indicated with arrow marks $(100 \mathrm{X}$, bar $=7 \mu \mathrm{m}) ; \mathrm{G}=$ Basidium with spore $(40 \mathrm{X}$, bar $=15 \mu \mathrm{m})$ and $\mathrm{H}=$ Basidium without spore $(100 \mathrm{X}, \mathrm{bar}=7 \mu \mathrm{m})$.

Another species $S$. chartaceum is quite similar to $S$. angulisporus by the color and morphology of the basidiome. S. angulisporus is distinguished from S. chartaceum by its larger internodes, rugulose and sub-tomentose basidiomes, nodulose to verrucose basidiospores and a 
very abundant and compact basal mycelium in contrast to smaller internodes, smooth surface basidiomes, echinulate with long spines basidiospores and a scarce and loosely attached basal mycelium of $S$. chartaceum.

Ramaria invali (Cott and Waket.) Donk, an allied species of $S$. angulisporus was mentioned by Alam and Amin (2007). Moreover, in recent times, Tanni et al. (2020) reported Ramariopsis kunzei (Fr.) Corner from Dhaka, which is often deceiving to $S$. angulisporus. Though both the fungi belong to Clavariaceae family, in $R$. kunzei, basidiomes are radially branched, hymenium amphigenous and basidiospores not angular whereas in S. angulisporus basidiomes are branching in one plane, mostly flat, hymenium often unilateral and basidiospores angular.

\section{Acknowledgements}

The authors are grateful to the authorities of Bangladesh Ministry of Science and Technology for financial assistance in the research project and Bangladesh Forest Department for their cooperation during conducting this study.

\section{References}

Alam, M.N. and Amin, S.M.R. 2007. Ramaria invali (Cott and Waket.) Donk. In: Siddiqui, K.U., Islam, M.A., Ahmed, Z.U., Begum, Z.N.T., Hassan, M.A., Khondker, M., Rahman, M.M., Kabir, S.M.H., Ahmad, M., Ahmed, A.T.A., Rahman, A.K.A. and Haque, E.U. (eds.) Encyclopedia of Flora and Fauna of Bangladesh, Vol. 2. Cyanobacteria, Bacteria and Fungi. Asiatic Society of Bangladesh, Dhaka. Pp 350.

Alam, N., Amin, R., Khan, A., Ara, I., Shim, M.J., Lee, M.W. and Lee, T.S. 2008. Nutritional analysis of cultivated mushrooms in Bangladesh: Pleurotus ostreatus, Pleurotus sajor-caju, Pleurotus florida and Calocybe indica. Mycobiology 36(4):228-232.

Banerjee, S.N. 1947. Fungus flora of Calcutta and suburbs I. Bulletin of Botanical Society of Bengal. 1: $37-$ 54.

Corner, E.J.H. 1950. A monograph of Clavaria and allied genera, Oxford University Press, London.

Corner, E.J.H. 1953. Addenda Clavariaceae. III. Annals of Botany London, N.S. 17(66): 47-368.

Corner, E.J.H. 1966. Clavarioid genera and Thelephora from the Congo. Bull. Jard. Bot. État Bruxelles 36(3): 257-279.

Corner, E.J.H. 1970. Supplement to "A monograph of Clavaria and allied genera". Beihefte Zür Nova Hedwigia 33: 299.

Desjardin, D.E. and Perry, B.A. 2015. A new species of Scytinopogon from the island of Príncipe, Republic of São Tomé and Príncipe, West Africa. Mycosphere 6(4): 433-440.

Donk, M.A. 1954. The generic names proposed for Hymenomycetes-III. "Clavariaceae". Reinwardtia 2: 441493.

Dutta, A.K., Pradhan, P., Roy, A. and Acharya, K. 2012. Agaricales of West Bengal, India. I. Clavariaceae: Clavaria and Scytinopogon. Indian J. Applied \& Pure Bio. 27(1): 53-58.

Garcia-Sandoval, R., Difuentes, J. and Villegas, M. 2004. First record of Scytinopogon from Mexico, with notes on its systematics. Mycotaxon. 89(1) 185-192.

Hosen, I. and Ge, Z.W. 2020. Clarkeinda trachodes (Agaricales, Basidiomycetes), first record from Bangladesh. Mycotaxon 118: 331-336.

Hosen, I. and Li, T.H. 2017. Two new species of Phylloporus from Bangladesh, with morphological and molecular evidence. Mycologia 109(2):277-286.

Meijer, A.A.R. 2006. Preliminary list of the Macromycetes from the Brazilian state of Paraná. Bol. Mus. Bot. Munic. 68: 1-55. 
Prance, M. and Fechner, N. 2017. Collecting and preserving fungi specimens, a manual. Queensland Herbarium, Department of Science, Information Technology and Innovation, Brisbane QLD 4001, Australia.

Rumainul, M.I. and Aminuzzaman, F.M. 2016. Macro fungi biodiversity at the central and northern biosphere reserved areas of tropical moist deciduous forest region of Bangladesh. J. Agric. Ecol. Res. Intl. 5(4): 1-11.

Shamsi, S. 2019. Checklist of dDeuteromycteous fungi of Bangladesh I1. J. Bangladesh Acad. Sci. 43(2): $113-122$

Tanjim, A., Aminuzzaman, F.M., Rahaman, M. and Tanni, J.F. 2019. Biodiversity, distribution and morphological characterization of macrofungi in Sylhet and Moulvibazar under tropical evergreen and semi-evergreen forest regions of Bangladesh. Int. J. Adv. Res. 7(11): 567-589.

Tanni, J. F., Aminuzzaman, F.M., Ahmed, M. and Rahaman, M. 2020. Diversity and distribution of macro fungi in some selected parks and gardens of Dhaka city, Bangladesh. Asian J. Biol. 9(1): 23-43.

(Manuscript received on 2 July 2021; revised on 7 December 2021) 